\title{
Coagulase-negative staphylococci causing endocarditis after cardiac surgery
}

\author{
D. C. E. SPELLER AND R. G. MITCHELL \\ From the Gibson Laboratories, Radcliffe Infirmary, and the Department of Pathology, Churchill Hospital, \\ Oxford
}

SYNOPSIS The laboratory findings in seven cases of endocarditis caused by coagulase-negative staphylococci are presented. The usefulness of biochemical characterization of the strains in diagnosis and the selection of antibiotics for prophylaxis and treatment are discussed.

Bacterial endocarditis is a well recognized complication of cardiac operations, especially those which involve the insertion of valve prostheses, and is commonly due to coagulase-negative staphylococci (Denton, Pappas, Uricchio, Goldberg, and Likoff, 1957). Untreated, it runs a relentless and fatal course. Treatment with appropriate chemotherapy may be curative, but the mortality rate is nevertheless high, perhaps in the region of $75 \%$. Surgical intervention is sometimes indicated for patients for whom medical treatment has failed, but the results of medical and surgical treatment are not very different (Braimbridge, 1969). Clearly some patients reach the stage when they are too ill to withstand surgical replacement of the prosthesis. It seems probable that suitable prophylactic chemotherapy given just before and during the operation will reduce the incidence of bacterial endocarditis (Armoury, Bowman, and Malm, 1966) but this has not been the finding in some studies (Goodman, Schaffner, Collins, Battersby, and Koenig, 1968; Sande, Johnson, Hook, and Kaye, 1972) and the best method of protecting these patients has yet to be defined (Garrod and O'Grady, 1971). Very little has been published to guide one in the correct choice of chemotherapy for established infections. The diagnosis of endocarditis due to coagulase-negative staphylococci is rarely straightforward, since these are also the commonest contaminants in blood cultures.

In this report we consider some of the problems which were encountered in the laboratory in making the diagnosis and in selecting chemotherapy in a series of patients with endocarditis caused by coagulase-negative staphylococci.

Received for publication 3 May 1973.

\section{Methods}

Several methods of blood culture were used, but essentially $5 \mathrm{ml}$ volumes of blood were inoculated into $100-300 \mathrm{ml}$ of glucose broth and of $0.1 \%$ sodium thioglycollate broth, with or without $0.05 \%$ sodium polyanethol sulphonate. Bottles were subcultured at two days and seven days, or when visible growth occurred. In many cases pour-plates were also prepared by combining $1 \mathrm{ml}$ of blood with $19 \mathrm{ml}$ of agar. Most blood specimens were also cultured in hypertonic medium (Rosner, 1970) for isolation of forms with impaired cell walls. For patient 7 certain cultures were performed by the membrane filtration technique (Millipore).

Representative isolates were biotyped by BairdParker's (1963) system of classification. Staphylococcus subgroup II strains were further characterized by the extended series of tests proposed by Holt (1969), consisting of acid production from galactose, fructose, and mannose, gelatin hydrolysis, and urease production.

Antibiotic sensitivities were initially determined by the disc-diffusion method and confirmed by the tube-dilution method (Garrod and O'Grady, 1971). Bactericidal action of antibiotics used singly and in pairs was tested by the method of Garrod and Waterworth (1969), but with subculture at two, six, and 20 hours. An inoculum of $10^{5}-10^{6}$ viable units per $\mathrm{ml}$ was used, and care was taken to allow time for absorption of antibiotic into the plate before the inoculum was spread. In some instances subculture to large volumes of broth was carried out to verify bactericidal effect. The following agents were used, each at a final concentration of $10 \mu \mathrm{g}$ per $\mathrm{ml}$ : penicillin (benzylpenicillin), cloxacillin, cephaloridine, lincomycin, fusidic acid, streptomycin, 


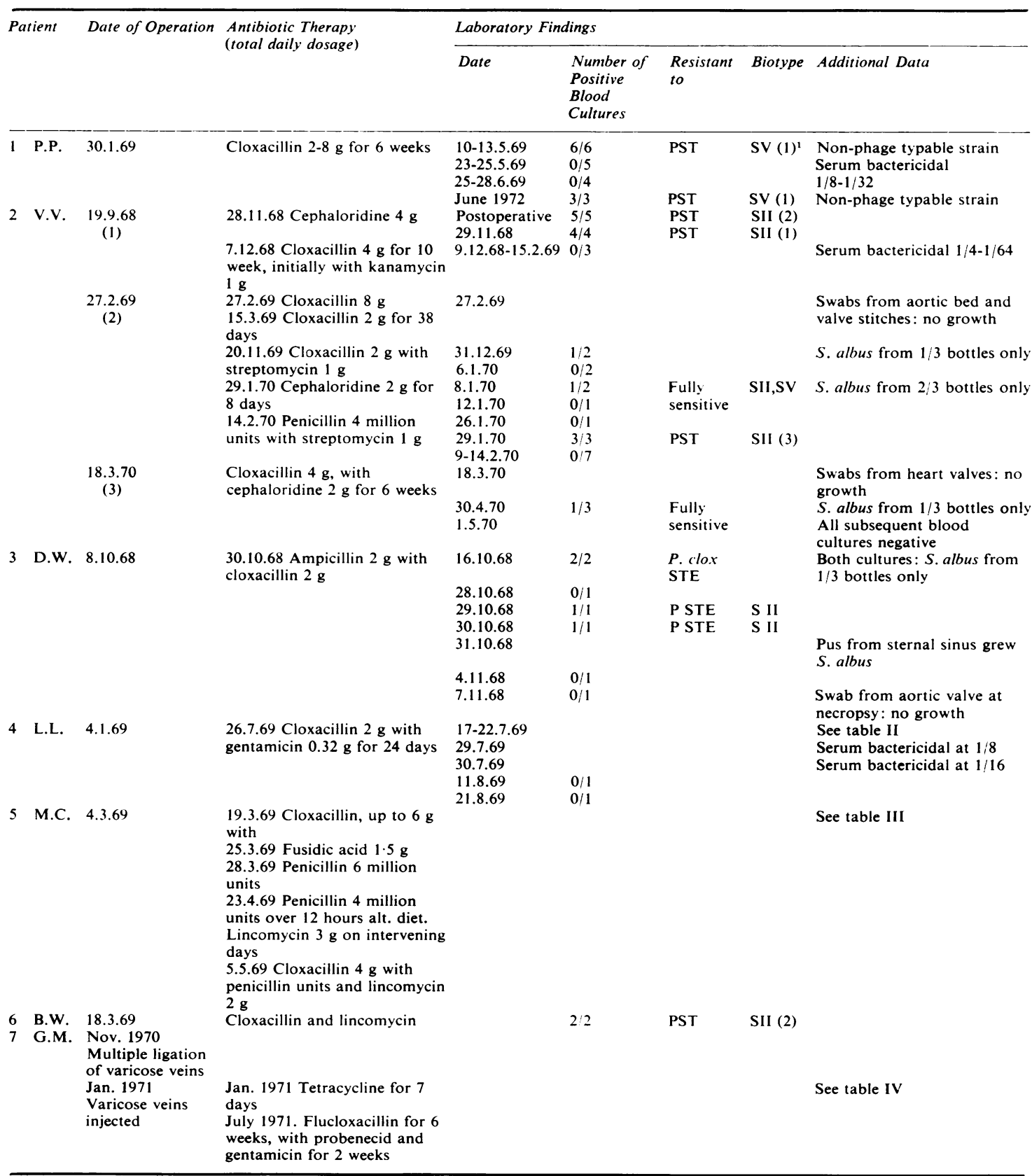

Table I Treatment and laboratory findings in seven cases of endocarditis caused by coagulase-negative staphylococci $\mathbf{P}=$ penicillin, $\mathbf{S}=$ streptomycin, $\mathrm{T}=$ tetracycline, $\mathrm{E}=$ erythromycin, Clox = cloxacillin. ${ }^{1}$ Number of strains tested given in parenthesis.

gentamicin, and kanamycin. Later, rifampicin was similarly studied, using the antibiotic combinations and concentrations described by Peard, Fleck,
Garrod, and Waterworth (1970) for the treatment of $S$. aureus endocarditis.

The bacteriostatic and bactericidal activities of 
serum specimens were determined by doubly diluting serum in nutrient broth inoculated with the patient's own organism to give a viable content of $10^{5}$ per $\mathrm{ml}$.

\section{Case Reports}

Six patients underwent cardiac surgery for the insertion of aortic and/or mitral valve prostheses, and subsequently developed endocarditis caused by coagulase-negative staphylococci (table I). None of the patients received antibiotic cover for the operation, but all received a postoperative course of ampicillin 1-2 $\mathrm{g}$ daily for an average of two weeks. Patient 2 received antibiotic cover during her second and third cardiac operations performed at another hospital. Following the diagnosis of endocarditis, all patients received prolonged antibiotic treatment in high dosage, resulting in adequate serum bactericidal levels. An additional patient was studied who contracted a coagulase-negative staphylococcus infection of a natural valve following ligation and injection of varicose veins. The relevant laboratory findings are shown in table I; some of these require comment.

\section{PATIENT 1}

A six weeks' course of cloxacillin appeared to eradicate the infection in 1969. However, an isolate which was stored was found to be indistinguishable from a strain isolated from the patient's blood in 1972 following recurrence of endocarditis. It appeared possible that colonization of the valve had persisted for the whole of this period.

\section{PATIENT 2}

Following operation, at least five blood cultures taken at another hospital yielded coagulase-negative staphylococci which were regarded as contaminants. However, two of these isolates were similar in biotype and antibiotic resistance pattern to a strain subsequently isolated after endocarditis was diagnosed clinically. Biotyping was also of value in detecting contaminant strains (8 January 1970) after a second operation for reasons other than infection. Later, serial blood cultures grew organisms which resembled each other in biotype and antibiotic resistance pattern, and this led to a diagnosis of endocarditis and to a third operation under antibiotic cover which appeared to eradicate the infection.

\section{PATIENT 4}

No fewer than 56 coagulase-negative isolates were obtained from individual pour-plates and bottles. Large and small colonial forms were repeatedly isolated and subcultures from either type of colony usually produced mixed growths. Subcultures from three isolates were studied in detail (table II). In spite of differences in colonial morphology, antibiotic resistance and biotype, they belonged to the same phage type, and were regarded as variants of the same strain showing marked dissociation of properties.

\begin{tabular}{|c|c|c|c|c|c|c|c|}
\hline $\begin{array}{l}\text { Refer- } \\
\text { ence } \\
\text { No. }\end{array}$ & $\begin{array}{l}\text { Colony } \\
\text { Form }\end{array}$ & & $\begin{array}{l}\text { sist- } \\
\text { to }\end{array}$ & Lactose & $\begin{array}{l}\text { Phos- } \\
\text { phatase }\end{array}$ & $\begin{array}{l}\text { Bio- } \\
\text { type }\end{array}$ & Phage Type \\
\hline 15 & $\begin{array}{l}\text { Large } \\
\text { Small }\end{array}$ & $\begin{array}{l}\mathbf{T} \\
\mathbf{T}\end{array}$ & $\begin{array}{l}\mathbf{E} \\
\mathbf{E}\end{array}$ & $\begin{array}{l}+ \\
+\end{array}$ & + & $\begin{array}{l}\text { SII } \\
\text { SV }\end{array}$ & $\begin{array}{lll}275 & 459 & 275 A \\
275 & 459 & 275 A\end{array}$ \\
\hline 17 & $\begin{array}{l}\text { Large } \\
\text { Small }\end{array}$ & E & & - & $t$ & $\begin{array}{l}\text { SII } \\
\text { SII }\end{array}$ & $\begin{array}{lll}275 & 459 & 275 A \\
275 & 459 & 275 A\end{array}$ \\
\hline 35 & $\begin{array}{l}\text { Large } \\
\text { Small }\end{array}$ & $T$ & $\Gamma$ & + & $\overline{+}$ & $\begin{array}{l}\text { SV } \\
\text { SII }\end{array}$ & 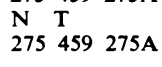 \\
\hline
\end{tabular}

Table II Characters of coagulase-negative staphylococci isolated from patient 4

$\mathrm{T}=$ tetracycline; $\mathrm{E}=$ erythromycin.

\section{PATIENT 5}

Details of the isolates are given in table III. Strains isolated early on were resistant to tetracycline and sensitive to erythromycin, whereas later isolates were sensitive to tetracycline and resistant to erythromycin. This may have indicated a recurrence of endocarditis due to a different organism. However, the development of erythromycin resistance could have resulted from treatment with lincomycin, since staphylococcal resistance to the two antibiotics is related. Subsequent isolates differed in their sensitivity to lincomycin, and again it was uncertain whether this indicated strain variation or infection by multiple strains.

\begin{tabular}{|c|c|c|c|}
\hline Date & Biotype & Resistant to & $\begin{array}{l}\text { Chemotherapy in } \\
\text { Progress }\end{array}$ \\
\hline $\begin{array}{l}17.3 .69 \\
18.3 .69 \\
21.3 .69 \\
22.3 .69 \\
29.4 .69 \\
1.5 .69 \\
2.5 .69 \\
3.5 .69 \\
5.5 .69 \\
12.5 .69\end{array}$ & $\left.\begin{array}{l}\text { SII } \\
\text { SII } \\
\text { SII } \\
\text { SII } \\
\text { SII } \\
\text { SII } \\
\text { SII } \\
\text { SII } \\
\text { SII } \\
\text { Colonial } \\
\text { variants } \\
\text { at } \\
\text { necropsy }\end{array}\right\} \begin{array}{ll}1 & \text { SII } \\
2 & \text { SII } \\
3 & \text { SII } \\
4 & \text { SII }\end{array}$ & $\begin{array}{l}\text { P S T } \\
\text { P S T } \\
\text { P S T } \\
\text { P S T } \\
\text { P E Clox } \\
\text { P E L } \\
\text { P S } \\
\text { P S Clox L } \\
\text { P S Clox L } \\
\text { P S E Clox } \\
\text { P S E Clox } \\
\text { PS E Clox } \\
\text { P S E Clox L }\end{array}$ & $\begin{array}{l}\text { Ampi } \\
\text { Ampi } \\
\text { Clox } \\
\text { Clox } \\
\text { P L on alternate days } \\
\text { P L on alternate days } \\
\text { P L on alternate days } \\
\text { P L on alternate days } \\
\text { P Clox } L\end{array}$ \\
\hline
\end{tabular}

Table III Characters of coagulase-negative staphylococci isolated from patient 5

Ampi = ampicillin; $\mathbf{C l o x}=$ cloxacillin; $\mathbf{E}=$ erythromycin $; \mathbf{L}=$ lincomycin; $\mathbf{P}=$ benzylpenicillin; $\mathbf{S}=$ streptomycin; $\mathbf{T}=$ tetracycline. 
PATIENT 7

Serial blood cultures yielded mixed colonial forms which caused considerable confusion at first, and suggested the possibility of repeated contamination. A total of 26 representative isolates were obtained using various culture techniques including pourplates and membrane filtration. The diagnosis of endocarditis was substantiated when most of the isolates were found to be of similar biotype and sensitivity pattern. Three isolates of different biotypes, two of which also had different antibiotic sensitivities, were discarded as contaminants (table IV).

\begin{tabular}{|c|c|c|c|c|}
\hline Date & $\begin{array}{l}\text { Reference } \\
\text { Number }\end{array}$ & $\begin{array}{l}\text { Colonial } \\
\text { Variants }\end{array}$ & Biotype & Resistant to \\
\hline \multirow[t]{2}{*}{23.6 .71} & 16538 & A, B & SV & Penicillin \\
\hline & 16539 & $\mathrm{~A}, \mathrm{~B}$ & SV & Penicillin \\
\hline \multirow[t]{5}{*}{24.6 .71} & 16544 & $\mathrm{~A}$ & SV & Penicillin \\
\hline & 16544 & B & M3 & $\begin{array}{l}\text { Penicillin, cloxacillin, } \\
\text { fusidic acid, novobiocin }\end{array}$ \\
\hline & 16575 & & SIV & Penicillin \\
\hline & 16602 & $\mathrm{~A}$ & SII & $\begin{array}{l}\text { Penicillin, neomycin, } \\
\text { kanamycin }\end{array}$ \\
\hline & 16602 & $\mathrm{~B}$ & SV & Penicillin \\
\hline 25.6 .71 & 16732 & $\mathrm{~A}, \mathrm{~B}, \mathrm{C}$ & SV & Penicillin \\
\hline \multirow[t]{2}{*}{26.6 .71} & 16782 & A. B & SV & Penicillin \\
\hline & 16785 & A & SV & Penicillin \\
\hline 28.6 .71 & 16977 & A-F & SV & Penicillin \\
\hline
\end{tabular}

Table IV Characters of coagulase-negative staphylococci isolated from patient 7

\section{Antibiotic Sensitivity Tests}

The results of antibiotic sensitivity tests carried out on representative pathogenic strains from all patients are summarized in table $\mathrm{V}$.

The following general conclusions emerged from testing the bactericidal activity of antibacterial agents alone and in combinations.

1 All the isolates were resistant to penicillin, but variable results in the experiments may have reflected variable penicillinase production. In none,

\begin{tabular}{lcc}
\hline & Sensitive & Resistant \\
\hline Benzylpenicillin & 0 & 10 \\
Cloxacillin & 6 & 4 \\
Cephaloridine & 10 & 0 \\
Lincomycin & 9 & 1 \\
Fusidic acid & 10 & 0 \\
Streptomycin & 1 & 9 \\
Gentamicin & 10 & 0 \\
Kanamycin & 9 & 1 \\
\hline
\end{tabular}

Table $\mathrm{V}$ Antibiotic sensitivities of 10 representative pathogenic strains of coagulase-negative staphylococci isolated from seven patients however, did penicillin achieve satisfactory rapid sterilization of the culture.

2 When strains were sensitive to aminoglycosides these agents achieved very rapid sterilization of the cultures, in two to six hours. All 10 strains showed this effect with gentamicin, nine strains with kanamycin, and a single strain with streptomycin.

3 In most cases cloxacillin alone and cephaloridine alone were bactericidal or caused marked reduction in bacterial count, but the effect occurred more slowly than with the aminoglycosides.

4 Lincomycin alone, fusidic acid alone, and erythromycin alone usually failed to sterilize the cultures, even at 20 hours; they were generally antagonistic to penicillin, cloxacillin, and cephaloridine in combination studies, reducing the rate and the completeness of the kill.

5 Rifamide gave very variable results, ranging from a rapidly bactericidal effect to inhibition only.

6 No appreciably synergistic combination of antibiotics was demonstrated.

\section{Discussion}

In order to diagnose endocarditis caused by coagulase-negative staphylococci, it is necessary to distinguish between genuinely positive blood cultures resulting from bacteraemia, and those contaminated by organisms derived from the skin of the patient or operator, unsterile apparatus or media, or the air. Reliance is usually placed on repeated isolation of a similar organism from several consecutive blood cultures (hence the large number of specimens cultured from some of the patients reported here), and on growth in all of several cultures from each specimen, including pour-plates. However, bacteraemia in both 'medical' and 'surgical' endocarditis may be irregular (Quinn and Cox, 1964; Wilson and Stuart, 1965). In case 7, culture by membrane filtration yielded only 2 viable units per millilitre of blood.

It is clearly important to establish whether it is the same strain which is being repeatedly isolated. Strains may sometimes be differentiated by their antibiotic sensitivity patterns, as in cases 2,5 , and 7 , but minor differences may not be significant or merely represent acquired resistance to an antibiotic, and a considerable number of strains are indistinguishable because they remain generally sensitive to antibiotics. Strains may differ in stable biochemical characters, and in the present study all strains were biotyped by the methods described by Baird-Parker (1963). Unfortunately, this system of classification is only of limited value, since Staphylococcus subgroups II and $\mathrm{V}$ are relatively common both as skin commensals (Baird-Parker, 1962) and 
as the causative organisms in endocarditis. Indeed, Baird-Parker (Baird-Parker, 1965; International Journal of Systematic Bacteriology, 1971) has now combined these two subgroups as biotype 1 of Staphylococcus epidermidis, since strains which are phosphatase-negative by the plate test may be found positive by the more sensitive test in fluid culture described by Pennock and Huddy (1967). Holt (1969) reported that staphylococci colonizing ventriculo-atrial shunts and causing bacteraemia were almost invariably Staphylococcus subgroup II strains. He subdivided this subgroup by an extended range of biochemical tests, but in our hands these gave variable results and did not assist significantly in differentiating strains. Recently, Verhoef, van Boven, and Winkler (1971) described an experimental phage-typing system for coagulasenegative staphylococci, particularly those of biotype I, which should prove invaluable in characterizing strains isolated from blood specimens. Representative strains from patient 4 , which differed in biotype, antibiotic sensitivity patterns, and colonial morphology, were examined by Professor R. E. O. Williams, who reported that with one exception, they were all of the same phage type $275,459,275 \mathrm{~A}$. These findings indicate that the characters used in biotyping may not always be stable among strain variants. A system of serotyping would usefully complement phage typing in characterizing strains, but is not at present available. Biotyping may sometimex reveal or confirm the presence of a contaminant strain of different subgroup among a series of isolates, as in cases 2 and 7 . However, mixed infections sometimes occur, as illustrated by case 5 , in which more than one strain was probably isolated from the blood at different times during life, and also from the valve at necropsy. This may have indicated infection by multiple strains at operation, or superinfection during intravenous treatment (Darrell and Garrod, 1969).

All the staphylococci in this series were resistant to penicillin and isolates from two patients were resistant to cloxacillin (minimum bactericidal concentration more than $25 \mu \mathrm{g}$ per ml). Quinn and Cox (1964), reporting on 16 cases of coagulase-negative staphylococcus endocarditis seen between 1953 and 1962 , found that all of nine 'medical' patients who acquired their infections outside hospital had penicillin-sensitive strains, whereas six of seven patients with postcardiotomy endocarditis had penicillin-resistant strains. Geraci, Hanson, and Giuliani (1968), reporting on 23 patients seen from 1958 to 1966 , found only two penicillin-resistant strains among 15 in the medical group, and surprisingly, only one among eight in the surgical group, an overall incidence of $13 \%$. Corse and
Williams (1968) commented on the high frequency of resistance to penicillin, streptomycin, and tetracycline among coagulase-negative cocci derived from all hospital sources, and found that $9 \%$ of their strains were resistant to cloxacillin. Most of the strains isolated from our patients were similarly resistant to multiple antibiotics and provided formidable problems in the choice of antibiotic therapy. All the isolates were sensitive to cephaloridine (minimum bactericidal concentration less than $1 \mu \mathrm{g}$ per $\mathrm{ml})$. Although cross resistance between cloxacillin (and related drugs) and the cephalosporins is usual with Staphylococcus aureus (Garrod and Waterworth, 1971), this is by no means true for coagulase-negative strains (Kjellander, Klein, and Finland, 1963; Sabath, Barrett, Wilcox, Gersteain, and Finland, 1969). Cephalothin is a less nephrotoxic cephalosporin than cephaloridine, and may be a better choice for long-term therapy when indicated.

All the isolates in the present series were sensitive to gentamicin and to fusidic acid, and all but one to kanamycin and to lincomycin, the strain resistant to the latter being first isolated after the patient had received treatment with lincomycin. All our isolates except those from the 'medical' case (patient 7) were resistant to streptomycin. None of the patients reported here had received prophylactic chemotherapy before or at operation, though most received ampicillin immediately afterwards and this may have resulted in the selection of penicillin-resistant strains.

No synergism was demonstrated with any combination of antibiotics, but it is possible that individual antibiotics, notably the aminoglycosides, were so effective on their own in the concentrations used that any interaction was concealed. Disappointingly, the penicillins and the aminoglycosides were not synergistic against strains resistant to the latter group. We did not test the activity of trimethoprim-sulphamethoxazole combinations or vancomycin, although these may prove useful on occasions.

Other reports have stressed the difficulty of eradicating infection from prosthetic valves by chemotherapy (Geraci et al, 1968; Braimbridge, 1969; Sande et al, 1972). Only two of our six postcardiotomy patients survived. Patient 2 was subjected to further valve replacement on two occasions. Patient 1 appeared to have been cured by antibiotic therapy, but further blood cultures taken three years later yielded strains which were indistinguishable from those isolated initially, and the possibility of a prolonged subclinical infection cannot be ruled out.

It is probably inadvisable to rely on any single antibiotic to achieve a cure in staphylococcal 
endocarditis. Our experiences do not enable us to recommend any particular combination of antibiotics as being markedly superior to others and likely to be effective in all patients; in each case the ultimate choice must depend on the laboratory findings. However, the aminoglycosides (except streptomycin) showed a remarkably rapid and complete bactericidal action against our series of strains, and the combination of a penicillin such as cloxacillin with gentamicin would seem to be a sound initial choice if the infecting organism is shown by disc testing to be sensitive to both antibiotics. This should be verified by testing the bactericidal activity of the patient's serum against the infecting organism. If the strain is resistant to either or both of these antibiotics, then an alternative combination must be selected from the results of combined antibiotic bactericidal tests. Cloxacillin and gentamicin would also appear to be a rational combination for prophylaxis in cardiac surgery.

We are indebted to Dr E. M. Buzzard, Dr J. G. G. Ledingham, Dr G. de J. Lee, Professor A. E. Read, and Dr P. Sleight for permission to describe these patients, and to Professor R. E. O. Williams and Mrs B. A. Dean for bacteriophage typing.

\section{References}

Amoury, R. A., Bowman, F. O., Jr., and Malm, J. R. (1966). Endocarditis associated with intracardiac prostheses. J. thorac. cardiovasc. Surg., 51, 36-48.

Baird-Parker, A. C. (1962). The occurrence and enumeration, according to a new classification, of micrococci and staphylococci in bacon and on human and pig skin. J. appl. Bact., 25, 352-361.

Baird-Parker, A. C. (1963). A classification of micrococci and staphylococci based on physiological and biochemical tests. J. gen. Microbiol., 30, 409-427.

Baird-Parker, A. C. (1965). Staphylococci and their classification. Ann. N.Y. Acad. Sci., 128, 4-25.

Braimbridge, M. V. (1969). Cardiac surgery and bacterial endocarditis. Lancet, 1, 1307-1309.
Corse, J., and Williams, R. E. O. (1968). Antibiotic resistance of coagulase-negative staphylococci and micrococci. J. clin. Path., 21, $722-728$.

Darrell, J. H., and Garrod, L. P. (1969). Secondary septicaemia from intravenous cannulae. Brit. med. J., 2, 481-482.

Denton, C., Pappas, E. G., Uricchio, J. F., Goldberg, H., and Likoff, W. (1957). Bacterial endocarditis following cardiac surgery. Circulation, 15, 525-531.

Garrod, L. P., and O'Grady, F. (1971). Antibiotic and Chemotherapy, 3rd ed. Livingstone, London and Edinburgh.

Garrod, L. P., and Waterworth, P. M. (1969). Tests of combined bactericidal action. Association of Clinical Pathologists' Broadsheet 63.

Garrod, L. P., and Waterworth, P. M. (1971). A study of antibiotic sensitivity testing with proposals for simple uniform methods. J. clin. Path., 24, 779-789.

Geraci, J. E., Hanson, K. C., and Giuliani, E. R. (1968). Endocarditis caused by coagulase-negative staphylococci. Mayo Clin. Proc., 43, 420-434.

Goodman, J. S., Schaffner, W., Collins, H. A., Battersby, E. J., and Koenig, M. G. (1968). Infection after cardiovascular surgery. New Engl. J. Med., 278, 117-123.

Holt, R. (1969). The classification of staphylococci from colonized ventriculo-atrial shunts. J. clin. Path., 22, 475-482.

International Journal of Systematic Bacteriology (1971). ICNB Subcommittee on Taxonomy of Staphylococci and Micrococci Minutes. Int. J. Syst. Bact., 21, 161-163.

Kjellander, J. O., Klein, J. O., and Finland, M. (1963). In vitro activity of penicillins against Staphylococcus albus. Proc. Soc. exp. Biol. (N.Y.), 113, 1023-1031.

Peard, M. C., Fleck, D. G., Garrod, L. P., and Waterworth, P. M. (1970). Combined rifampicin and erythromycin for bacterial endocarditis. Brit. med. J., 4, 410-411.

Pennock, C. A., and Huddy, R. B. (1967). Phosphatase reaction of coagulase-negative staphylococci and micrococci. J. Path. Bact., 93, 685-688.

Quinn, E. L., and Cox, F., Jr. (1964). Staphylococcus albus (epidermidis) endocarditis: report of 16 cases seen between 1953 and 1962. Antimicrob. Agents and Chemother., 635-642.

Rosner, R. (1970). Comparison of a blood culture system containing liquoid and sucrose with systems containing either reagent alone. Appl. Microbiol., 19, 281-282.

Sabath, L. D., Barrett, F. F., Wilcox, C., Gerstein, D. A., and Finland, M. (1969). Methicillin resistance of Staphylococcus aureus and Staphylococcus epidermidis. Antimicrob. Agents and Chemother., 1968, 302-306.

Sande, M. A., Johnson, W. D., Jr., Hook, E. W., and Kaye, D. (1972). Sustained bacteremia in patients with prosthetic cardiac valves. New Engl. J. Med., 286, 1067-1070.

Verhoef, J., Van Boven, C. P. A., and Winkler, K. C. (1971). Characters of phages from coagulase-negative staphylococci. J. med. Microbiol., 4, 413-424.

Wilson, T. S., and Stuart, R. D. (1965). Staphylococcus albus in wound infection and in septicemia. Canad. med. Ass. J., 93, 8-16. 